\title{
Work Values and Job Attitudes in the Czech Republic between 1997 and 2005*
}

\author{
JIŘÍ VEČERNÍK** \\ Institute of Sociology, Academy of Sciences of the Czech Republic, Prague
}

\begin{abstract}
The article is conceived as a contribution to a critical reading of opinion data and the presentation of ISSP modules on Work Orientations from 1997 and 2005 in the Czech Republic. In the first part, some methodological problems regarding the inspection of work and job values are presented using examples drawn from previous research. In the second part, the framework of systemic transition is set up and hypotheses are presented regarding work values and attitudes from the perspective of gender and age, education and occupation. In the third part, a comparison is made of people's expectations regarding their work and jobs with their perceived fulfilment. In the fourth part, we consider the perceived location of workers between the distant worlds of family and firms and inspect factors of work and job satisfaction. In conclusion, we discuss the role of subjective perceptions in the economy and the question of a 'true' change in values during the transition.
\end{abstract}

Keywords: work values, job satisfaction, gender dimension, Czech Republic Sociologický časopis/Czech Sociological Review, 2006, Vol. 42, No. 6: 1219-1240

In recent decades, the developed world has seen important changes in the area of human labour. Economic activity, originally a matter of terrestrial pain and strain, became a positive behaviour, enriching human life on a mass scale. Post-modern society, according to Ronald Inglehart, replaces the values of survival with the values of security, and unleashes an opportunity for the 'cognitive mobilisation' of workers. The change in the nature of work itself, as well as related work values, is part of a comprehensive cultural change linked to economic development and leading people towards post-materialist values, individual life-styles, and civic participation [Inglehart 1990].

However, at the same time, work has become scarcer, and many people have become worse off as a result of unemployment. In the globalisation process, much

\footnotetext{
* This study was supported by grant no. 403/05/2769 from the Grant Agency of the Czech Republic for the project 'The Adjustment of the Czech Labour Force: Changing Job Structures, Wage Disparities and Work Orientations'. Thanks are due to Alena Nešporová, ILO Deputy Regional Director for Europe and Central Asia, and Péter Róbert, senior researcher of TÁRKI in Budapest, for important comments and suggestions.

** Direct all correspondence to: Jiří Večerník, Institute of Sociology, Academy of Sciences of the Czech Republic, Jilská 1, 11000 Prague 1, Czech Republic, Jiri.Vecernik@soc.cas.cz
}

(C) Sociologický ústav AV ČR, Praha 2006 
routine work moves out of developed countries and into poorer countries, where wage costs are negligible. Work that involves intrinsic values of human development is far from a mass phenomenon, and the number of jobs is continually decreasing: "In fact, from being a burden, work has become a privilege" [Dahrendorf 1990: 144]. Paid work has become a basic status-forming activity of Western civilisation. However, it brings not only satisfaction, but also risks, which have a stressful effect on people's lives [Beck 1992; Beck 2000].

Both the positive and negative features of recent developments relating to work are present in contemporary societies, including the transition countries of Central and Eastern Europe (CEE hereafter), the Czech Republic included. The transformation of the economy and society inherited from the communist system generated new problems. There is a deep legacy of relaxed attitudes towards employment, which had previously been obligatory, while the expectations concerning social protection are high. The pressure put on the quality and intensity of work performance is weak, and large sections of the labour force are reluctant to accept work flexibility in a job. While the transformation of the external institutional framework is over, it is still going insofar as the intrinsic characteristics of work and job attitudes are concerned.

There is a considerable difference in the amount of attention paid to such intrinsic dimensions of work and jobs in the 'West' and in the 'East'. In the West, scholars are trying to determine the current qualitative changes in this particular area in relation to a general value change, and whether this involves a change from materialism to post-materialism, from national economies to globalisation, or from social networks to an atomised social web. Important branches of economic sociology and socio-economics focus on studying the social setting of human work [Kallerberg 1977; Yankelovich et al. 1985; Tilly and Tilly 1994; Sennett 1998; Swedberg 2003; Beckert and Zafirovski 2006].

No societal transformation can be accomplished without taking into account value dimensions. As often happens, less attention is given to values in those places where they are of greater importance. In fact, the process of abandoning communism has been overburdened with assumptions about what is the 'natural' (pleasure-seeking) behaviour of people and its alleged 'real' (= economic) base. In steering the transition process, macro-economics preceded micro-economics, the neoclassical approach preceded the institutional one (within economics), economics preceded sociology (within the social sciences), and the description of the assumed 'objective' state preceded any explanation taking into account 'subjective' attitudes (within sociology). In such a sequence, the issue of the value dimensions of real behaviour was almost shifted right off the stage.

In an effort to partially fill in the existing gap in knowledge, this article is conceived as a contribution to a critical reading of opinion data on work and jobs, and the presentation of ISSP modules on Work Orientations from 1997 and 2005. In the first part, some methodological problems regarding the inspection of work and job values are introduced using examples drawn from previous research. In the second part, some hypotheses are presented regarding work attitudes from the perspective 
of gender, age and education. In the third part, a comparison is made of people's job and work expectations with their perceived fulfilment. In the fourth part, workers' perceptions of where they stand between the remote worlds of family and firm are considered and some factors of work and job satisfaction are examined. In conclusion, the role of subjective perceptions in the economy and the question of a true change in values during the transition are discussed.

\section{Methodological difficulties and previous research}

Any analysis of work values exposes numerous methodological problems. The key problem is that values cannot be indicated directly. 'True' human values, as such, can be identified by means of a complex comparative socio-historical analysis (such as Alexis de Tocqueville's Democracy in America). Opinion surveys are also helpful, although never sufficient alone. There are, however, various concepts that can be used to describe human perceptions, and we can therefore at least distinguish between preferences and attitudes on the one hand and values and norms on the other. Generally, the latter are considered more general and durable than the former. For instance, Michael Hechter sees values as relatively general and durable criteria of evaluation:

As such, they differ from other concepts like preferences (and attitudes) and norms. Like values, preferences (and attitudes) are internal, but unlike values, preferences are liable rather than durable and particular rather than general. Whereas norms are also evaluative, general and durable, they are external to actors and - in contrast to values - require sanctions for their efficacy. [Hechter 1994: 321]

Whatever general framework and definitions of individual categories are set, difficulties surface in the process of collecting evidence. The traditions and socioeconomic climate of a country may seriously constrain the calibration of a given value scale. As is often demonstrated on a general level, 'subjective' human happiness does not depend very much on 'objective' well-being [Diener et al. 1993]. The given general framework of values (economic, social, and cultural) and the standard of value judgments in a country are probably more important for forging people's opinions than are the careful indicators of economic performance. National mentalities and the specifics of a regime matter, as do changing reference contexts - this is the case of the transition. How experienced or 'trained' the population is at answering surveys largely determines the consistency of answers, too.

After 1989, people had to re-learn to formulate their opinions freely, with deliberation and in consistent frameworks. In the beginning, they were often asked about issues they have never reflected in their minds. The former routine of mechanical acceptance of everything issued 'from above' in the public sphere was combined with excessive criticism in the private sphere. Firm opinions survived in ar- 
eas where people were indoctrinated by an ideology, without any deeper understanding of problems. The differences between the East and the West are particularly salient in those areas.

With regard to inequality, in a study based on the 1999 ISSP survey, Marc Suhrcke concluded, "results do confirm the hypothesis of significant differences in attitudes. People living in transition countries tolerate existing income differences significantly less than people in the West, even after we control for the usual determinants of attitudes to inequality and for the actual level of income inequality" [Suhrcke 2001: 25]. As the issue of inequality was the main issue proclaimed by the communist regime, systemic differences are quite understandable. However, the results of a comparison of countries' views on this issue are ambiguous - as the most egalitarian country appears to be Portugal, while egalitarian attitudes in the Czech Republic are equal to those in France.

If we look at other, similarly complex issues, such as the welfare state, it is even harder to find connections between the 'objective' state of affairs in a country and people's attitudes - or, from a different perspective, consistent and clear country or regional patterns. This was shown in an analysis of the public's support for different welfare regimes among five Western countries, based on data from the 1996 ISSP module on 'the role of government'. Giuliano Bonoli [2000: 449] found "the way surveys questions are answered can be best understood with reference to norms and values that have traditionally dominated national practices and discourses". It is possible to assume that the same would be found when comparing countries within the boundaries of the CEE region, but the picture would probably be more blurred.

Unlike such 'ideological' issues, the area of work and job values is plagued by greater ambiguity. Under the communist regime, work itself was endowed with the dichotomous status of being simultaneously a right and an obligation. As the communist ideology promoted the value of work too aggressively, it was adversely devalued in real life. People learned to prefer components of work other than its prestige and their own achievements through formal labour. More often, primary importance was given to such features as the absence of any supervisory control or less strict working conditions, which permitted less of a work burden and more hours of leisure, allowing time to perform informal jobs or bricolage at home.

Strictly speaking, analyses of work values are somewhat rare, even within the same 'family of nations'. Wolfgang Teckenberg and Michael Bayer [1999] compared the work values of (West) Germans and Italians (distinguishing between the centralnorthern and the southern regions in the latter) using the 'European Values Study' of 1980 and 1990. They found that while for Italians work mainly represented a channel of social integration, it possessed much more intrinsic values in the former West Germany, where work was and is regarded more in terms of rational criteria, such as a means of income. In former West Germany, the economic sphere of life is more clearly distinguished from family life and leisure. In Italy, work and social life are more mixed, which, as the 1990 data showed, is somewhat similar to the case in Neue Länder. 
S.D. Harding and F.J. Hikspoors [1995] also used the 'European Values Study' to compare thirteen Western countries. Based on earlier analytical findings, they were able to distinguish the factors of 'personal development' and 'comfort and material conditions', noting the increasing importance of the former. While Northern European countries 'form the most fertile ground for empowered employees', Southern Europeans ascribe rather more importance to the 'value of comfort'. However, at the same time, 'employees are becoming more demanding of their employers', not only in terms of the wage amount itself, but also in terms of the relationship between individual work performance and reward [Ibid.: 445-448].

As the comparison between East and West Germany suggests, the value of work in the countries of real socialism was higher, but only because of the stronger importance of the workplace's socialisation function [Meulemann 1996]. In this sense, communist countries were similar to the Southern European, less developed nations, where work also has more of a social than an economic function. This aspect in particular was raised by women in opinion surveys in communist Czechoslovakia, where the labour-force participation of women was very high and the weight of the gender dimension in earning disparities was much more important than elsewhere (see below for an explanation).

Márton Medgyesi and Péter Róbert used the 1997 ISSP data to compare work satisfaction in five groups of European countries, grouped and ordered according to descending levels of satisfaction: Scandinavian countries, Western Europe, the EU periphery (Portugal and Spain), less developed transition countries (Bulgaria, Russia), and more developed transition countries (Czech Republic, Hungary, Poland, Slovenia). Subjective variables (the discrepancy between expectations and their fulfilment in individual work characteristics) appeared to be much better predictors than objective characteristics, among which personal income, self-employment, and a supervisory position scored highest [Medgyesi and Róbert 2003].

While Western populations score higher in asking for an independent and interesting job, Eastern countries prefer work rewards and job promotions. While Western populations stick more to the intrinsic values of work (initiative, responsibility, interest, promotion), Easterners prefer the external conditions of the job (pay, hours, vacations, not too much pressure). What people demand from employment is currently better met by jobs in the West than in the East. Consequently, CEE people appear to be less satisfied with their jobs than EU people, first and foremost owing to unsatisfactory salaries [Večerník 2004].

The most interesting case is the two parts of Germany, which, given that the two regions of what was formerly one country (albeit culturally diversified) were separated for decades by a political and economic regime, represents a kind of live experiment. It is therefore surprising that there was no real difference in the respondents' perceptions of work in the two parts of unified Germany in 1998, and their perceptions have not changed at all since 1993. While the objective situation certainly did change, in the sense that there was greater similarity of work-styles and job insecurities, its subjective perception did not change at all [Habich, Noll and 
Zapf 1999]. Job satisfaction was also constant during the decade between 1990 and 2000, remaining very similar in both 'Germanies' [Christoph 2002].

The experience of the Czech Republic was different - not stability in this case, but rather a return to previously shared opinions. In the early 1990s the 'capitalist virtues' of self-reliance and the need for personal adaptation spread somewhat, but they were substituted by the population's exaggerated sense of confidence in their own skills and their reliance on the state; simply put, the declared liberal attitudes of the early period were clearly only verbal. The weakening self-assessment and relaxed attitudes of the Czech population are evident in the widening gap between these attitudes and experts' evaluations of various aspects of the Czech labour force, in other words, between the view of the same situation from the inside and from the outside [Večerník 2003].

Nevertheless, the 'history' documented in this article is more recent. Owing to the available data, the story of the transition cannot be described in full length. The first ISSP module 'Work Orientations' was collected in the Czech Republic in 1997, i.e. when the biggest part of privatisation was nearing a close and the labour market had been established. It can be assumed that in the sphere of public opinion the 'learning period' was by that time already over and therefore the data can be regarded as consistent and comparable over time. Nevertheless, regardless of the time span covered by the data, the short story must be situated within the context of the longer history of transition and create a picture of this change.

\section{The explanatory framework}

During the period of economic reform in the CEE countries, labour market problems were described with the vocabulary and methodology of mainstream economics. There was little place for examining the human values related to economic behaviour and work. In addition to the primary focus being on the economy, there were several other reasons for this neglect: First, measuring human values is complicated because it is necessary to rely on opinion data. Second, there are no time series on this subject, which would enable comparisons with the communist past. Third, there is no research tradition like economic sociology or social anthropology in the CEE countries that would facilitate this type of inquiry.

In the transition, it was assumed that 'tough' labour market conditions would lead to more demanding criteria and a more intense work performance, and consequently would also help counter the previously social character of work. However, the combination of the kind of experience people were accustomed to from the past and the 'velvet conditions' of the early transition led many people to re-assume a high subjective assessment of their abilities and to leave the responsibility for job security to the state [Večerník and Matěju 1999: 295]. A comparison of the 1991 and the 1999 World/European values surveys showed a considerable decrease in the importance ascribed to both social and self-fulfilling aspects of work in the Czech Republic [Mareš 2001: 77]. 
Instead of the purely administrative arrangements of labour, transition brings about individual, contractual, and much freer labour relations within a different context. It was a complex process, but when both simplified and put into a more general framework it can be conceived as a transition from the 'basic needs principle', asserted by the communist regime, to the 'market principle' implied by the capitalist regime. This is assumed to be a major qualitative and systemic change, which occurs behind the scenes and is revealed in quantitative shifts described by statistics. The relevance of this explanatory tool, formulated to examine distributions of personal earnings and household incomes [Večerník 2006], could also be applied in the area of work and job related values.

The 'basic needs principle' means that the main focus is on what is necessary for the reproduction of the labour force. This principle was explicitly formulated by Marx as the primary mechanism for rewarding (and exploiting) hired labour by capitalists: presumably, they do not pay for the labour itself, but only ensure the reproduction of the labour force. Wrongly interpreted by Marx as capitalism's base for the production of surplus value (appropriated by the capitalist class), this principle was in reality applied by the communist ruling class. Conversely, 'market principle' is understood to be the forging of closer links between human capital, labour performance and results with rewards and incomes. This highly stylised opposition can manifest itself in various characteristics of workers, although vaguely and unevenly.

The lack of data on attitudes, their historical embeddedness, and the other standard limitation of 'soft' data obviously make this analysis more difficult than an analysis of earnings and income. First, there is no comparative survey from the early 1990s or earlier describing the initial enthusiasm about reforms or before that the situation under the communist regime. Second, it is necessary to take into account the learning process connected with the practice in communicating various opinions, as people became more experienced in answering survey questions consistently. The interview situations in 1997 and 2005 were certainly not identical, but there are no controlling questions to test the consistency of responses. Third, the survey samples are too small to allow a more detailed analysis. If we cannot overcome these limitations, we must at least be aware of them.

Below is an overview of possible changes in the characteristics of workers within the proposed stylised explanatory framework of the systemic shift from the 'basic needs principle' to the 'market principle' (Scheme 1).

In terms of gender, adherence to the 'basic needs principle' under the communist regime resulted in women's earnings being conceived as necessary but supplementary to family income. It was not individual performance but the reproduction of the labour force that was important. Therefore, women's work could easily be downgraded - and even entire branches of light manufacturing and administration could be downgraded when the male labour force was transferred to 'more productive' branches. This generated a vicious circle: women received low wages because they worked in 'female' branches and occupations. This did not prevent women from being installed as 'soldiers of labour' alongside men, under the false label of equal rights 


\section{Scheme 1. The role of various characteristics affecting work and earnings under two principles (stylised)}

\begin{tabular}{lll}
\hline Characteristic & Needs principle & Market principle \\
\hline The role of gender & women's position is derived & women's position is \\
& from the family, their & authentic, their earnings are \\
earnings are supplementary & derived from the labour \\
to household income & market
\end{tabular}

The role of age/experience

The role of education

The role of occupation and industry

Dependent vs. independent work the life cycle is crucial, the wage curve by age is curved, seniority is valued more than education

education is a public good, there is no reason to reward $i t$, priority is given to manual, productive labour

physical energy and time spent working matter; production branches have priority, the tertiary educated only get what remains

no independent work in the $\mathrm{CR}$, only in the informal economy the life cycle is not important, the wage curve by age is flat, experience is valued less than education education is a private good, it brings considerable returns, priority is given to managerial and creative labour

managerial skills and innovation matter; strategic services, finance and applied research have priority

independent work expands and provides chances for promotion and better earnings; often second jobs

and emancipation. However, their work was regarded as secondary by society and the related expectations from work were moderate and focused on social contacts.

It cannot be said that in the market system the work that men and women perform always has the same status and is treated equally and that discrimination does not exist. The 'needs principle' is also applied under market conditions. According to wage surveys, the gender gap decreased somewhat in the Czech Republic after 1989: In 1988, the average wage of full-time female workers was $71 \%$ of that of their male counterparts, by 1996 it had risen to 77\%. But in 2001-2005 it grew again to roughly a stable $75 \%$ [CSO 2006]. ${ }^{1}$ Nevertheless, this is only a comparison of averages, behind which women's earnings are much more dispersed. The effect of gender on earnings disparities in fact fell quite dramatically: while in 1988, gender

${ }^{1}$ In 2000, women's gross hourly wages as a percentage of men's ranged between $68 \%$ in United Kingdom and 86\% in Sweden [Eurostat 2003]. It looks like the Czech Republic is located somewhere in the middle of the range. 
alone explained $31 \%$ of the variance of earnings; by 2002 it accounted for a mere $10 \%$ of the variance [Večerník 2006]. This attests to the accuracy of our assumption regarding the different role of gender under the market regime.

In terms of age, the 'basic needs principle' mimics the pattern of family costs over the individual stages of the life cycle. Under the communist regime, only families with children had chance to get a flat. Therefore, the start of a person's economic life and their family life occurred within a very short period of the life cycle [Večerník 1977]. At the same time, seniority was valued more than education. Once the revolutionary phase - with its catchphrase 'youth forward' - was over, being older was considered a precondition for occupying higher positions. However, all preferences tied to age were overturned in the transition - seniority became rather a burden, while a lack of experience could be made up for and accumulated in the market regime. Also, a gap emerged between the start of economic life and family life.

In terms of education, there has indeed been a striking and apparent change. Under Marxist doctrine, intellectual and managerial work was not considered 'directly productive' and was regarded rather as just sharing in the yields of manual labour. Under communist doctrine, education was allegedly provided free of charge 'by the working class' and, therefore, all its returns belonged to everyone. Although some differences in earnings between educational levels were maintained, they were small indeed, particularly in pre-1989 Czechoslovakia and even compared to other socialist countries [Večerník 1991]. In the market regime, education is becoming the primary axis, either because, as labour economics asserts, it is a measure of human capital and (as assumed) also of the productivity of labour, or because it is an indicator of other characteristics that we are not able to measure, such as the character of labour and work performance.

Occupation and industry, according to the 'needs principle', matter in terms of the physical energy and time workers are required to invest. Production branches were much better rewarded in the communist regime (being 'directly productive' in Marxist vocabulary) than services were (considered as 'non-productive'). According to the 'market principle', they matter in terms of their productivity, efficiency, and innovation. In this regard the situation started changing rapidly after 1989, although not consistently. In terms of industries, services expanded, but it was particularly financial services that did, while public services were left behind. Health and social services improved slightly, but education and research stagnated for a long time. In terms of occupations, the main change concerned management which became much more important and valued, the higher the more.

There is yet another dimension that characterises the transformation and is of crucial significance for the change in system - dependent vs. independent work. Former Czechoslovakia was more consistent than other CEE communist countries in banning all traces of the capitalist regime and the 'bourgeoisie'. In order to impose complete control over the economy and society, personal creativity and initiative were suppressed - even if they would have enhanced the results of the planned economy. After 1989 the entrepreneurship that was revived was able to draw on var- 
ious sources - capitalist roots, the informal economy developed under communism, and the new process of privatisation, in many cases linked to networks and political capital developed under the previous regime. Despite all the barriers to enterprise in the form of bureaucracy, the doors to private initiatives were flung open. ${ }^{2}$

However, reality has differed from the stylised image of a 'free market regime'. In fact, change has been slow, complicated, and not streamlined. Markets are always only partial and imperfect, and their impact is always limited. There are still many deep-rooted patterns, both legitimate (the needs of family reproduction) and not (female occupations). In any case, the effects of assigned characteristics have been weakening, while the effects of achievement characteristics have been strengthening during the transition. This is the story originally demonstrated in the case of earnings and income distribution [Večerník 2001] and which we are now attempting to prove for the area of work values.

\section{Work expectations and their fulfilment}

The analysis below is based on sub-samples of economically active respondents from the ISSP modules 'Work Orientations' 1997 and 2005. By coincidence, the first year of data collection was also a year when an economic recession occurred and unemployment began to rise. It is little surprise, then, that work had increasingly come to be seen as 'pain and strain': in 1997, 41\% of respondents in the labour force reported that they only work to earn money, while in 2005 the figure was 56\%. What is rather surprising is that only a minor change in the character of work is reported during the eight years under observation - one-fifth of respondents in both surveys declared that they engage in hard physical work and the same percentage declared their work to be stressful. In 2005, 39\% of respondents reported that they arrive home exhausted, as opposed to 34\% in 1997.

The data provide a partial insight into the multi-dimensional and multifaceted character of work. There are two separate sets of questions to be compared (Table 1). The first set of characteristics concerns the expected quality of work and job, while the second describe the respondent's current job in the same terms. We can see that no tremendous changes occurred between 1997 and 2005 with regard to the desired characteristics of work, especially among men, while women more often expected an independent, well-paid and career-oriented job. In terms of the characteristics of the respondents' actual jobs, only male respondents more frequently reported having well-paid and career-oriented jobs. Women feel stagnation in connection with those characteristics and are less likely to consider their work as interesting for a person and independent relative to their expectations.

\footnotetext{
2 The comparative evidence based on the number of days needed to establish a new firm indicates the difficult conditions confronting Czech entrepreneurs. See more about the issue in Benáček [2006].
} 
Table 1. Expected and fulfilled characteristics of work and job (index 0-100)

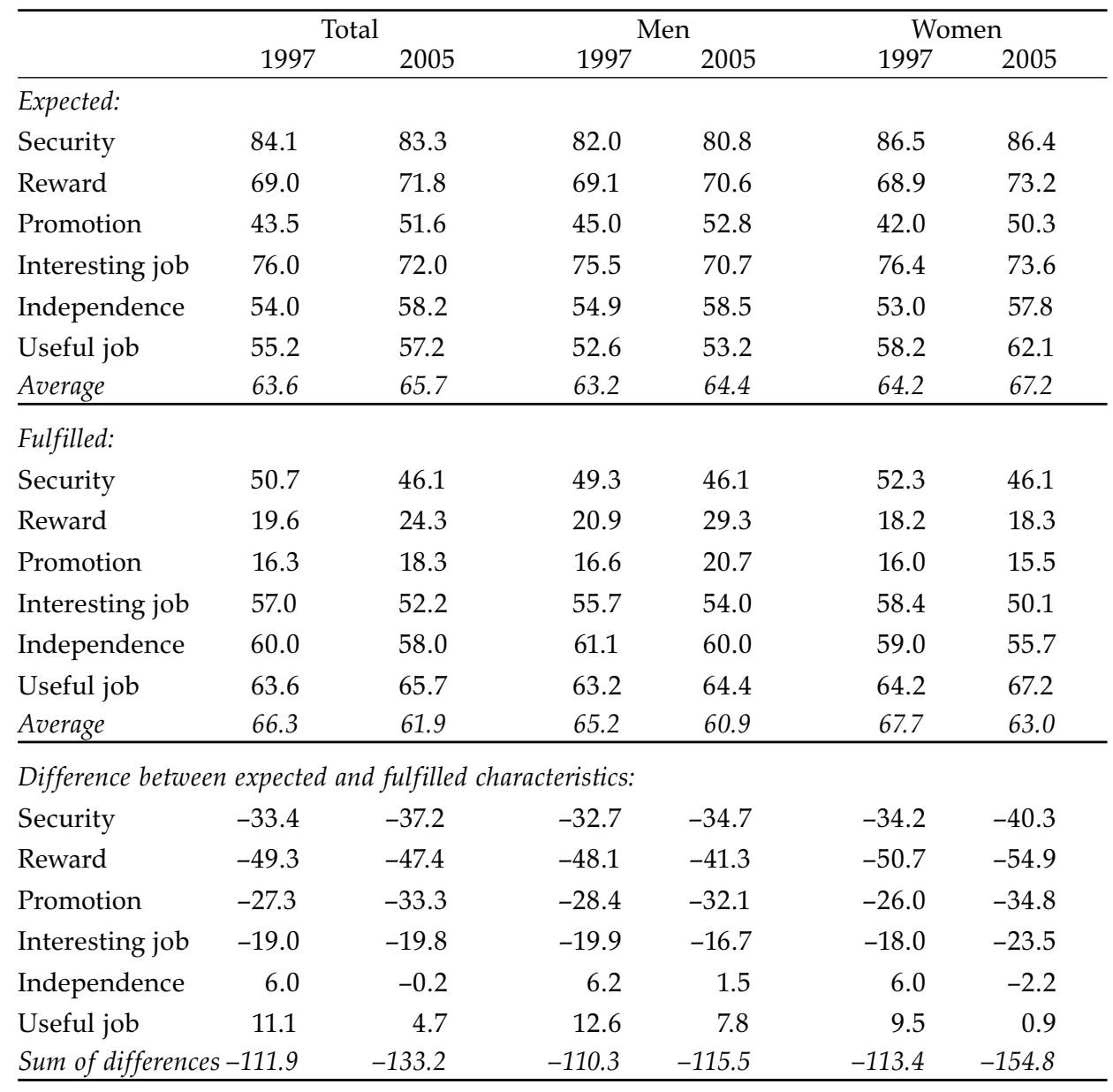

Source: ISSP 1997 and 2005. Economically active respondents.

The index was computed from the answers 'very important' $=100$, 'important' $=75$, 'neither important nor not important' $=50$, 'not important' $=25$, and 'not important at all' $=0$.

If we compare both views (e.g. hypothetically how well the respondent's job corresponds with their expected values), the highest dissatisfaction is with regard to rewards, followed by dissatisfaction with job security, and dissatisfaction with opportunities for promotion. Gender appears here as a variable of utmost importance. While the levels of fulfilment of expectations were about the same among men and women in 1997, by 2005 they had become quite different. The gap between expected characteristics and their actual fulfilment remains about the same for men in 
Table 2. The degree of fulfilment of various characteristics of work and job correlated with workers' characteristics (Spearman's rank order correlation coefficients)

\begin{tabular}{lcccccc}
\hline & Sex & Age & Education & Occupation & Earnings & Self-employed \\
\hline 1997 & & & & & & \\
Security & -0.02 & 0.00 & $0.17^{* *}$ & $-0.20^{* *}$ & $0.16^{* *}$ & 0.04 \\
Reward & -0.03 & 0.05 & $0.25^{* *}$ & $-0.25^{* *}$ & $0.23^{* *}$ & $0.16^{* *}$ \\
Promotion & 0.04 & 0.03 & -0.01 & -0.02 & 0.03 & 0.08 \\
Interesting job & 0.04 & 0.08 & $0.10^{*}$ & $-0.18^{* *}$ & $0.17^{* *}$ & 0.06 \\
Independence & -0.02 & 0.01 & $-0.12^{* *}$ & 0.03 & 0.02 & $0.10^{*}$ \\
Useful job & -0.01 & 0.05 & 0.00 & -0.02 & 0.02 & 0.01 \\
\hline 2005 & & & & & & \\
Security & $-0.10^{* *}$ & -0.04 & 0.06 & -0.06 & 0.10 & $0.12^{* *}$ \\
Reward & $-0.18^{* *}$ & 0.06 & $0.19^{* *}$ & $-0.14^{* *}$ & $0.36^{* *}$ & $0.12^{* *}$ \\
Promotion & -0.03 & 0.06 & -0.04 & 0.04 & $0.12^{*}$ & 0.06 \\
Interesting job & $-0.12^{* *}$ & 0.04 & 0.05 & -0.08 & $0.25^{* *}$ & $0.08^{*}$ \\
Independence & $-0.11^{* *}$ & 0.00 & $0.11^{* *}$ & $-0.11^{* *}$ & $0.18^{* *}$ & $0.12^{* *}$ \\
Useful job & $-0.11^{* *}$ & -0.03 & 0.01 & -0.02 & $0.15^{*}$ & 0.05 \\
\hline
\end{tabular}

Source: ISSP 1997 and 2005. Economically active respondents.

** Correlation is significant at the 0.01 level (2-tailed)

* Correlation is significant at the 0.05 level (2-tailed)

Note: Spearman's rank correlation coefficients are used on occasions when it is not convenient to assign actual values to variables, but only to assign a rank order to the instances of each variable. It is also a better indicator when the relationship between two variables is non-linear. The same conclusions can be reached using Kendall's Tau coefficient.

both years, but there is a considerable increase in dissatisfaction among women. This increase relates to the possibilities for promotion in particular, while the increase in dissatisfaction with rewards, securities, and job interest is also important but smaller.

Although the period of time under observation was short, the change is striking and informative. Evidently, the public awareness of equal rights and opportunities is increasing, and the topic is frequently addressed by the media and politicians with EU policy support. ${ }^{3}$ Therefore, it is natural that women increasingly have similar expectations about promotion at work as men. Exploratory factor analysis (not presented here) reveals that, unlike 1997, the structure of the qualities women expect from work resembles that of men much more in 2005, with interesting and in-

${ }^{3}$ Here this refers to EU initiatives and recommendations in the area of the equal rights of men and women, gender mainstreaming, etc. [EC 2005]. 
dependent work as the core variables. While, for example, expectations concerning rewards are better matched among men in 2005 than in 1997, the opposite is true for women. This corresponds well with the hypothesis that the expectations and requirements regarding the position of women in the labour market are changing and becoming less connected with traditional gender attributes. However, the labour market is responding unevenly, so there are fewer women in standard (full-time and open-ended) and higher positions [Jurajda and Paligorova 2006].

As women's perceptions shift in the direction of higher expectations, which are less often met, the importance of the gender gap increases. While in 1997 the gender gap was relatively negligible in this regard, by 2005 it had become a substantial factor, most strikingly so in the area of rewards, where men and women experienced opposite shifts regarding the fulfilment of their expectations. This supports the hypothesis about the increasing homogeneity of labour values in terms of gender, however much it is thus far an idea rather than a reality. With similar expectations but a lower status, women are increasingly critical of their actual positions (Table 2).

In contrast, age differences remained insignificant. This corresponds with the point made above about the decline in the importance of the life cycle and age-related preferences in the 'market regime' compared to the 'basic needs regime' and the decline in the importance of the seniority applied under the communist system. We have only to bear in mind that in this case correlation coefficients have less explanatory power (underestimating the actual effect of the variable) owing to the curvilinear character of careers and their various associations in objective and subjective status. The comparison of 1997 and 2005 reveals a moderate shift from higher satisfaction among older workers to higher satisfaction among younger workers.

Important differences emerge when the data are broken down by education, which is particularly significant for attained earnings and independence at work. While these two characteristics maintained their importance in both years, there was a marked decline in the effect of education on obtaining a secure and interesting job. The rise in educational qualifications combined with a not very dynamic economic and occupational structure necessarily produces such an effect. ${ }^{4}$ Roughly the same process occurred in the correlations with broad occupational categories, although the association between the two variables is rather weak. Earnings rose distinctly in importance and became the most substantial correlate of the fulfilment of work and job expectations.

A separate dimension is the difference between dependent and independent work. On the one hand, self-employment or entrepreneurship allows more freedom and incentives for personal fulfilment, but on the other hand, it also entails more problems and stress. Satisfaction with rewards, promotion opportunities, and the

\footnotetext{
${ }_{4}$ This is what occurs in Western societies. As the share of persons with higher education rises, they increasingly spread over a larger area of the occupational hierarchy, towards filling in the lower ladders. This also affects the returns on education, which start to stagnate or decrease [Večerník 2006].
} 
interest and independence of the work is certainly higher among the self-employed. The main change between 1997 and 2005 concerns, somewhat paradoxically, job security. The reason is that appreciation of a job as secure has decreased generally, but among the self-employed less than among employees. The result is a growing difference between both groups. ${ }^{5}$

As the explanatory power of such key labour market variables as education and occupation is generally decreasing, we can raise questions about the increasing subtleness of the differences in the labour market. Instead of striking dimensions easily accessible for statistics and surveys, the finer characteristics of workers are moving to the fore. Also, 'soft skills' matter, such as adaptability and cooperativeness, but also a capacity for personal development. Gradually the type and quality of school will matter more than the level of education. In all other respects, standard variables are experiencing the same process of decreasing explanatory power as they are in earnings disparities [Večerník 2006].

\section{Work commitment and job satisfaction}

The re-establishment of the market regime produced two sorts of people at the extremes of work commitment - the workaholic on the one hand and welfare-dependent persons on the other. The majority of people are located somewhere in between, usually inclined towards taking on less of a work burden and having more time for family and leisure. In both ISSP surveys, most respondents declared they already spend enough time on work and do not have enough time for their family, friends, and leisure. This perceived imbalance between work and leisure time somewhat grew in strength between 1997 and 2005. Provided the use of time was left to the discretion of respondents, in 1997, 11\% of economically active respondents would have devoted more time to work, but just $8 \%$ in 2005 , while $68 \%$ would have spent more time on hobbies and leisure in 1997, and 70\% in 2005.

The decline in work commitment is quite striking. Between 1997 and 2005, the percentage of people reporting that they 'work only as hard as one has to' almost doubled (from 13\% to $23 \%$ ) while the percentage of those declaring that they 'make a point of doing the best work even if it sometimes interferes with one's private life' decreased considerably (from 53\% to 37\%). Another change occurred in the degree and structure of what determines the willingness to give work priority over personal life. This general attitude among people towards work is in 2005 determined less by workers' characteristics than in 1997, while the previously dominant distinction between employees and the self-employed became almost negligible.

\footnotetext{
${ }^{5}$ Alena Nešporová suggested here to stress that the majority of self-employed persons in the Czech Republic embarked on their entrepreneurship deliberately, with the expectations of having a better income and more interesting work, unlike in a number of other post-communist countries, like Hungary, where it was done more out of necessity, owing to a lack of jobs.
} 
Since the traditional division of tasks between spouses (the man as breadwinner and the woman as housewife) have become blurred, work and family roles come into conflict, and people have to work hard to reconcile them. Work and family which interferes with the other more? According to 2005 data (in 1997 no such mirror questions were posed), the interference does not appear that large. Among all employed respondents, job requirements are reported to harm (regularly or often) family life in $12 \%$ of cases, while the requirements of the family harm work in $5 \%$ of cases. If only respondents with dependent children (up to 18 years of age) are taken into account, the disharmony between family and work is only slightly higher - in $13 \%$ of cases work harms a person's family and in $8 \%$ family harms a person's work.

Women report a conflict between work and family less often than men. They are more ready to cope with both roles than men are, and they do not consider the two to be in conflict. As reported in one survey, in the absolute majority of families it is women who look after the family most: in $40 \%$ of families women always perform the household chores and in $47 \%$ usually; $38 \%$ of female respondents declare they give priority to family 'absolutely' and another $48 \%$ 'somewhat more'; among male respondents (when the 'absolutely' and 'somewhat' options are summed up) 39\% prefer the family, 33\% prefer a balance between work and family, and $22 \%$ declare a preference for work [Kuchařová et al. 2006].

The explanation of women's attitudes must be sought in the continuing acceptance of the traditional division of labour in the family, with the main burden on the side of women. Of course, the degree to which a person assumes their family role depends on their current and their desired employment status. It also depends on the real and the potential gender wage gap. In couples with two employees, the gap between the contributions made by husbands and wives to their joint family budgets decreased by 15 percentage points between 1988 and 2002 (measured as the percentage of the wife's wage to her husband's wage; in 2002 it was almost 80\%). However, the correlation between spouses' earnings became stronger after 1989: the Pearson coefficient (0.17 in 1988) increased from 0.29 in 1996 to 0.37 in 2002. Conversely, the share of employed married mothers decreased [Večerník 2006].

Regarding employees' relationships to their employer, it could be expected - given that Czechs prefer to be employees and to work in big companies or state organisations - that loyalty to an employer would be quite strong. However, this is true only to a small degree: strong agreement (among employees only) with the statement 'I am proud to be working for my firm or organisation' was expressed by $6-7 \%$ and moderate agreement by 33-34\% of respondents in both years. In contrast to the stability of this opinion, strong agreement with the statement 'I am willing to work harder in order to help the firm or organisation to succeed' decreased from $12 \%$ to $7 \%$ and moderate agreement from $46 \%$ to $42 \%$ between 1997 and 2005 . As a crossnational comparison of 1997 data showed, the level of loyalty to the employer is (like in other CEE countries) much lower than in Western countries [Večerník 2004].

The declining sense of loyalty towards the employer could theoretically be a manifestation of and coincide with the increasing work flexibility of Czech workers, 
Table 3. Job satisfaction, by sex and education (index 0-100)

\begin{tabular}{lcccccc}
\hline Education & \multicolumn{2}{c}{ Total } & \multicolumn{2}{c}{ Men } & \multicolumn{2}{c}{ Women } \\
& 1997 & 2005 & 1997 & 2005 & 1997 & 2005 \\
\hline Elementary & 68.0 & 67.2 & 66.4 & 74.8 & 68.6 & 65.1 \\
Lower secondary & 66.0 & 63.5 & 66.7 & 63.1 & 64.7 & 64.0 \\
Secondary & 71.2 & 71.8 & 69.4 & 71.3 & 72.7 & 72.2 \\
Tertiary & 74.9 & 69.8 & 74.7 & 71.4 & 75.4 & 66.5 \\
Total & 69.5 & 67.3 & 68.9 & 67.2 & 70.1 & 67.5 \\
\hline
\end{tabular}

Source: ISSP 1997 and 2005. Economically active respondents.

The index was computed on a seven-point verbal scale so that answer 'completely satisfied' $=100$ and 'completely dissatisfied' $=0$.

but again in reality this is evidently not the case. The information reported in statistics and sociological surveys reveals that the labour market is not very flexible and in recent years has stagnated. On the other hand, there are various tricky practices, such as informal cash payments supplementing the official minimum wage, engaging self-employed persons, hiring foreigners, and using contracting agencies to provide labour without any obligation on the employer's part. Instead of flexibility in the formal economy, active people balance on the brink of an informal economy seeking additional earnings. This corresponds very well with low level of loyalty to the employer.

Various features and dimensions of work and jobs contribute to overall job satisfaction (Table 3). The majority of employed Czechs are satisfied in their jobs, and there has only been a very slight decrease in this indicator despite growing anxiety about jobs and declared increasing job requirements. Nevertheless, work and job satisfaction is a complex indicator, as it can reflect the quality of the job (demands for skills, the amount of personal autonomy involved, the interest and usefulness of the work performed) or the ease of working conditions (work that is not demanding, within fixed hours, not harming family or personal life). It should of course be expected that the 'true' quality of a job will for the most part prevail in the perception of job satisfaction.

A person's perception how well their work satisfies their expectations of having an interesting job providing personal autonomy is what was most closely associated with overall job satisfaction in 1997, followed by job security. In 2005, satisfaction with job security became more important, and other factors somewhat less (Table 4). Yet another change has occurred over time, connected with the abovementioned characteristic of the 'easiness' of work. In 1997, the connection between satisfaction and the general attitude towards work was quite high, being significantly higher among those who see intrinsic values in the job and lower among those who see their job only as a source of income. In 2005, this association fell to one half of its previous value among men, but increased among women. More men 
Table 4. Fulfilled expectations of work and job correlated with job satisfaction (Spearman's rank order correlation coefficients)

\begin{tabular}{lllllll}
\hline & \multicolumn{2}{c}{ Total } & \multicolumn{2}{c}{ Men } & \multicolumn{2}{c}{ Women } \\
& $1997^{2}$ & 2005 & 1997 & 2005 & 1997 & 2005 \\
\hline Fulfilled: & & & & & & \\
Security & $0.30^{* *}$ & $0.33^{* *}$ & $0.35^{* *}$ & $0.37^{* *}$ & $0.24^{* *}$ & $0.29^{* *}$ \\
Reward & $0.19^{* *}$ & $0.23^{* *}$ & $0.22^{* *}$ & $0.24^{* *}$ & $0.16^{* *}$ & $0.24^{* *}$ \\
Promotion & $0.14^{* *}$ & $0.14^{* *}$ & $0.18^{* *}$ & $0.16^{* *}$ & 0.08 & $0.12^{*}$ \\
Interesting job & $0.46^{* *}$ & $0.44^{* *}$ & $0.45^{* *}$ & $0.50^{* *}$ & $0.48^{* *}$ & $0.37^{* *}$ \\
Independence & $0.32^{* *}$ & $0.25^{* *}$ & $0.39^{* *}$ & $0.28^{* *}$ & $0.25^{* *}$ & $0.21^{* *}$ \\
Useful job & $0.27^{* *}$ & $0.26^{* *}$ & $0.17^{* *}$ & $0.25^{* *}$ & $0.39^{* *}$ & $0.26^{* *}$ \\
\hline Difference between & expected and fulfilled characteristics: & & & \\
Security & $0.20^{* *}$ & $0.21^{* *}$ & $0.21^{* *}$ & $0.22^{* *}$ & $0.19^{* *}$ & $0.19^{* *}$ \\
Reward & $0.19^{* *}$ & $0.16^{* *}$ & $0.20^{* *}$ & $0.14^{* *}$ & $0.19^{* *}$ & $0.18^{* *}$ \\
Promotion & 0.06 & $0.09^{*}$ & 0.07 & $0.11^{*}$ & 0.05 & 0.07 \\
Interesting job & $0.28^{* *}$ & $0.22^{* *}$ & $0.24^{* *}$ & $0.27^{* *}$ & $0.32^{* *}$ & $0.16^{* *}$ \\
Independence & $0.10^{*}$ & $0.09^{*}$ & $0.12^{*}$ & 0.08 & 0.08 & 0.10 \\
Useful job & 0.07 & 0.03 & 0.02 & 0.02 & $0.14^{*}$ & 0.05 \\
\hline
\end{tabular}

Source: ISSP 1997 and 2005. Economically active respondents.

** Correlation is significant at the 0.01 level (2-tailed)

* Correlation is significant at the 0.05 level (2-tailed)

For correlation coefficients see the note in Table 2.

than women are satisfied in their jobs, but seeing their job as a source of income only has become a far most important reason for this view.

This shift in the general attitudes towards work helps explain the fact that the degree to which perceived satisfaction is determined by the specific work and job characteristics fell dramatically between 1997 and 2005. While in 1997 the variance in satisfaction explained by the standard characteristics of workers in regression analysis (not reported here) reached 7.5\%, the percentage in 2005 fell below 3\%. While education still matters (although less), sex and age do not. Even earnings and self-employment have lost most of their explanatory power. Thus, while work satisfaction has remained at almost the same level, its variance in the population cannot be explained statistically any more. It is likely to have completely shifted to an area of more subtle dimensions, which we are not able to measure. 


\section{Conclusion}

Only some vague tendencies can be reported among work and job values instead of clear conclusions. The gender dimension has come to the fore in work perception and has become at least as important as education. People prefer dependent employment but loyalty to the employer is on the decrease. While job satisfaction remains high, it is increasingly derived from job security and earnings. Overall, the common characteristics tied to workers are losing their explanatory power with regard to work attitudes. However, this does not mean that the world of attitudes has become detached from 'objective' life. Instead, it testifies to the inadequacy of our socio-economic variables, which fail to indicate more subtle levels and dimensions of people's socio-economic status and reasoning.

Here two additional aspects of work values warrant commenting: the question of their role in the economy and the question of a 'true' value change during the transition.

With regard to the first aspect, work values certainly play an important role in the economy, but not as simple a role as economists tend to assume. Job satisfaction is a frequent topic of study not only in sociological but also in economic literature [Freeman 1978]. There are many reasons for such an interest: more satisfied workers are assumed to perform better in their jobs, while less satisfied workers are more likely to perform poorly and to abuse any opportunity to reduce their work load, take sick leave, and eventually to leave their job. Work satisfaction is considered the best indicator of job quality. Positive associations between job satisfaction and work performance, stability, commitment, and loyalty to the employer are easy to demonstrate.

There is also a positive correlation between job satisfaction and labour productivity. Production sectors with higher levels of job satisfaction also display higher productivity, as the European Commission study based on the European Community Household Panel (ECHP) proves. There is a gap between highly skilled and elementary occupations. The importance of various personal and occupational characteristics for explaining job satisfaction is statistically significant but weak [EC 2002]. A regression analysis of a German joint 1992-1996 household panel cites workers' characteristics as accounting for $2 \%$ of the explained variance in West Germany and $4 \%$ in former East Germany. An analysis of a British household panel gives $4 \%$ of explained variance as owing to these characteristics [Van Praag and Ferrer-I-Carbonell 2004: 56-58].

From these points of view, the Czech results regarding change over time are rather confusing. While work productivity is higher in foreign-owned companies, that is exactly where the level of satisfaction is lower, as opposed to domestically owned companies. This difference became less pronounced over time, but it still exists. It could be that satisfaction is lower in firms where work organisation and control are tighter, which results in higher productivity but makes things less easy for workers. Between 1997 and 2005, work satisfaction decreased, particularly among professionals, which is the group in which intrinsic work values are concentrated. With regard to the low and decreasing degree to which workers' characteristics are 
determining job satisfaction, the variance these characteristics explain is lower in the Czech Republic is even lower than in Western countries.

With regard to the second aspect, whether the change in regime brought about a true value change in the field of work and jobs, we must avoid drifting to extremes, such as completely overlooking the change that occurred, or viewing the situations before and after transition as completely different. National value systems appear to be somewhat closed. As Pierre Bourdieu observed: "basic economic dispositions like needs, preferences and propensities - towards work, savings, investment, etc. are not exogenous, i.e. dependent on universal human nature, but endogenous, i.e. dependent on history, which also represents the economic cosmos in which they are required and re-compensated" [Bourdieu 1997: 51; author's translation].

This is partly - although not completely - at odds with the mainstream economic approach of always finding a "set of ordinal preferences so that every action of the history is rational" [Becker and Stigler 1977]. Regardless of the forces of globalisation, national value systems are indeed somewhat closed, and it is difficult for values to truly change. Here, the considerations of Mariano Grondona are very inspiring: "The process of economic development reaches a crisis when a nation passes from one stage to the next. It is at that moment when temptations arise... When a nation is rich, something other than the pursuit of wealth must be present in its value system so that the wealth generated never suffices. This non-economic 'something' may be salvation, survival, excellence, prestige, or even empire: any value that will always be wanting" [Grondona 2000: 44].

Numerous temptations arose after 1989, the main one lying in the immense wealth to be transferred to - relatively few - private hands, mostly on the basis of contacts within established networks. For the rest of the population, the huge and mostly obscure process of the redistribution of property was a signal that it is not exactly hard work, but other personal abilities that determine an individual's wealth and income. The relaxed attitude towards work, inherited from the previous regime, was thus again endorsed and maintained. The widespread critical examination of personal competencies that individuals undertook in the initial phase of transition was soon replaced with exaggerated expectations regarding career and pay, combined with requirements of continuing job security [Večerník 1996].

The social and cultural contexts matter no less than intrinsic values do. Of course, the tradition of self-fulfilment through work is deeper and, simultaneously, the competition tougher in the West. However, despite the continuing differences in work performance between the 'East' and the 'West', there is apparently no barrier between the two kinds of countries regarding what work values are expected and perceived. Work requirements are on average also weakening in the West, except at the extremes of the 'business elite' and the low-skilled 'flexi-workers' represented by foreign labourers. A similar process is occurring in advanced post-transition countries as well, and in the Czech Republic in particular, where relaxed attitudes towards work can no longer be attributed only to the legacy of the communist regime. 
JIŘí VEČERNÍK specialises in the study of the labour market, social policy, and economic inequality under transition, and has recently also been focusing on the institutional and value background of the post-communist transformation. He collaborates with the ILO, OECD and the European Commission. His most recent publications are 'Income Taxes and Benefits among Czech Employees (Czech Journal of Economics and Finance 1-2/2006) and 'Changing Social Status of Pensioners and the Prospects of Pension Reform in the Czech Republic' (Prague Economic Papers, 3/2006). His selected publications are available for downloading at http://ssm.com/author $=32949$

\section{References}

Bayer, M. and W. Teckenberg. 1999. 'Arbeit im Lebenskontext von Italiener und Deutschen.' Annali di Sociologia 13 (1-2): 173-206.

Beck, U. 1992. Risk Society. Towards a New Modernity. London: Sage.

Beck, U. 2000. The New Brave World of Work. Cambridge: Polity Press.

Becker, G.S. and G.J. Stigler. 1977. 'De gustibus non est disputandum.' American Economic Review 67: 76-90.

Beckert, J. and M. Zafirovski. (eds.) 2006. International Encyclopedia of Economic Sociology. London and New York: Routledge.

Benáček, V. 2006. "The Rise of the "Grand Entrepreneurs" in the Czech Republic and Their Contest for Capitalism.' Czech Sociological Review this issue.

Bonoli, G. 2000. 'Public Attitudes to Social Protection and Political Economy Traditions in Western Europe.' European Societies 2: 431-452.

Bourdieu, P. 1997. 'Le champ économique.' Actes de la recherche en sciences sociales. September 1997 (119): 48-66.

Christoph, B. 2002. 'Weiter deutliche Zufriedenheitsdifferenzen zwischen Ost und West trotz Annäherung in manchen Bereichen.' Informationsdienst Soziale Indikatoren 28. Mannheim: ZUMA.

CSO. 2006. Analysis of the Labour Market 2003-2005. Prague: Czech Statistical Office (in Czech).

Dahrendorf, R. 1990. Modern Social Conflict. An Essay on Politics of Liberty. Berkeley: University of California Press.

Diener, E., E. Sandvik, L. Seidlitz and M. Diener. 1993. 'The Relationship between Income and Subjective Well-Being: Relative or Absolute?' Social Indicators Research 28: 195-223.

European Commission. 2002. Employment in Europe. Recent Trends and Prospects. European Commission, Directorate-General for Employment, Social Affairs and Equal Opportunities Unit A1.

European Commission. 2005. Equality between Women and Men in the European Union. Brussels: European Commission, Directorate-General for Employment, Social Affairs and Equal Opportunities Unit G1.

Eurostat. 2003. Annual Gross Earnings Results from Member States, Acceding and Candidate Countries and Switzerland. Statistics in Focus. Population and Social Conditions. Theme 3-25/2003, by Anne Paternoster.

Freeman, R.B. 1978. 'Job Satisfaction as an Economic Variable.' American Economic Review 68: 135-141.

Grondona, M. 2000. 'A Cultural Typology of Economic Development.' Pp. 44-55 in Culture Matters. How Values Shape Human Progress, edited by L.E. Harrison and S.P. Huntington. New York: Basic Books. 
Habich, R., H.-H. Noll and W. Zapf. 1999. 'Subjektives Wohlbefinden in Ostdeutschland nähert sich Westdeutschem Niveau.' Informationsdienst Soziale Indikatoren 22. Mannheim: ZUMA.

Harding, S.D. and F.J. Hikspoors. 1995. 'New Work Values: In Theory and in Practice.' International Social Science Journal 145: 441-456.

Hechter, M. 1994. 'The Role of Values in Rational Choice Theory.' Rationality and Society 6: 318-333.

Inglehart, R. 1990. Culture Shift in Advanced Industrial Society. Princeton, NJ: Princeton University Press.

Jurajda, S. and T. Paligorova. 2006. 'Is There a “Glass Ceiling" in the Czech Republic?' Transition 17 (2): 21-22.

Kallerberg, A.L. 1977. 'Work Values and Job Rewards: A Theory of Job Satisfaction.' American Sociological Review 42: 124-43.

Kuchařová, V., S. Ettlerová, O. Nešporová and K. Svobodová. 2006. 'Employment and Childcare from the Viewpoint of Parents and Employers.' (in Czech) Prague: RILSA.

Mareš, P. 2001. 'The Czechs: Job and Work.' Czech Sociological Review 9: 69-84.

Medgyesi, M. and P. Róbert. 2003. 'Satisfaction with Work in a European Perspective: Center and Periphery, "Old" and "New" Market Economies Compared.' Review of Sociology 9: 43-68.

Meulemann, H. 1996. Werte und Wertwandel. Zur Identität einer geteilten und wiedevereinigten Nation. Weinheim/München: Juventa.

Sennet, R. 1998. The Corrosion of Character. New York: Norton.

Suhrcke, M. 2001. 'Preferences for Inequality: East vs. West.' Innocenti Working Paper 89. Florence: UNICEF, Innocenti Research Centre.

Swedberg, R. 2003. Principles of Economic Sociology. Princeton, NJ: Princeton University Press.

Tilly, C. and C. Tilly. 1994. 'Capitalist Work and Labour Markets.' Pp. 283-312 in The Handbook of Economic Sociology, edited by N.J. Smelser and R. Swedberg. Princeton, NJ: Princeton University Press and Russell Sage Foundation.

Van Praag, B. and A. Ferrer-I-Carbonell. 2004. Happiness Quantified. A Satisfaction Calculus Approach. Oxford: Oxford University Press.

Večerník, J. 1977. 'Dlouhodobé změny v některých meznících životního cyklu.' (Long-term Changes to Some Milestones in the Life Cycle) Demografie 19: 106-112.

Večernik, J. 1991. 'Earnings Distribution in Czechoslovakia: Intertemporal Change and International Comparison.' European Sociological Review 7: 237-252.

Večerník, J. 1996. Markets and People. The Czech Reform Experience in a Comparative Perspective. Aldershot: Avebury.

Večerník, J. 2001. 'From Needs to the Market: The Changing Inequality of Household Income in the Czech Transition.' European Societies 3: 191-212.

Večerník, J. 2003. 'Czech Capitalism, Institutional Environment, Work Values and Flexibility.' Pp. 69-86 in Why So Difficult? (in Czech), edited by J. Večerník, P. Matějů and O. Schneider. Prague: ISEA.

Večernik, J. 2004. 'Skating on Thin Ice: A Comparison of Work Values and Job Satisfaction in CEE and EU Countries.' International Journal for Comparative Sociology 44 (5): 444-471.

Večerník, J. 2006. 'Evolution or Revolution? Disparities in Earnings and Household Income in the Czech Republic 1988-2002.' IES FSV UK Occasional Paper 4. Prague: IES FSV UK.

Večerník, J. and P. Matěju (eds.) 1999. Ten Years of Re-building Capitalism. Czech Society after 1989. Prague: Academia.

Yankelovich, D., H. Zetterberg, M. Shanks and B. Strümpel. 1985. The World at Work. New York: Octagon. 


\section{International Social Survey Programme (ISSP)}

The ISSP is a long-term international research project that originated in 1983 and is based on international and inter-project cooperation in the social sciences. The number of participants has grown continually and currently rests at forty-one countries. Each year, a survey on one topic is conducted in all the participating countries. At annual working conferences, modules of survey questions are completed and accepted for the following year and proposals for questionnaires for the next year are presented to all participants for discussion. Data files from all countries are brought together, polished, controlled and archived by the Zentralarchiv für Empirische Sozialforschung at the University of Cologne (http://www.issp.org).

The Czech Republic has participated in the International Social Survey Programme (ISSP) since 1992. The module on 'Work Orientations' was collected for the first time in September 1997 by the agency STEM ( $N=1014$, of which 505 economically active) and for the second time in May 2005 by the agency SC\&C (N=1226, of which 660 economically active). This enables both a comparison across nations (so far only the first round) and over time. The survey contains data not just on opinions and beliefs about jobs and work but also on perceptions of working conditions and job stability. Similarly, it provides information about the workers' sense of loyalty to employers, as well as their willingness to stay in their present job or their intention to seek another job. 